\title{
Age, Growth, and Reproduction of Common Sole, Solea solea (Linnaeus, 1758) in the Sea of Marmara, Turkey
}

\author{
İsmail Burak DABAN ${ }^{1} * \mathbb{\oplus}$, Mukadder ARSLAN İHSANOĞLU ${ }^{1} \oplus$, Ali İSMEN ${ }^{1} \oplus$, \\ Cahide Çiğdem YIĞIN ${ }^{1} \mathbb{B}$
}

${ }^{1}$ Çanakkale Onsekiz Mart University, Faculty of Marine Science and Technology, 17100, Çanakkale, Turkey

*Corresponding Author: burakdaban@ comu.edu.tr

Received 22 January 2021; Accepted 06 April 2021; Release date 01 September 2021.

How to Cite: Daban, İ. B., Arslan İhsanoğlu, M., İşmen, A., \& Yığın, C. Ç. (2021). Age, growth, and reproduction of common Sole, Solea solea (Linnaeus, 1758) in the Sea of Marmara, Turkey. Acta Aquatica Turcica, 17(3), 395-408. https://doi.org/10.22392/actaquatr.866428

\begin{abstract}
This study revealed the length-weight relationship, age, growth and mortality parameters, and reproductive biology of the common sole, Solea solea in the Sea of Marmara, Turkey. Samplings were conducted with bottom trawl between March 2017 and December 2018 at 34 stations. The length-weight relationship was calculated as $\mathrm{W}=0.0082 \times \mathrm{TL}^{3.01}$. Ages were ranged between 1 and 5 years. The von Bertalanffy growth parameters were calculated as $\mathrm{L}_{\infty}=34.56 \mathrm{~cm}, \mathrm{~K}=0.48 \mathrm{y}^{-1}$, and $\mathrm{t}_{0}=-$ $0.01 \mathrm{y}$. The size at first maturity was $21.9 \mathrm{~cm}$ TL. The extended reproduction period was observed (from September to April). The rates of natural mortality $(\mathrm{M})$, total mortality $(\mathrm{Z})$, fishing mortality $(\mathrm{F})$, and exploitation rate $(\mathrm{E})$ were calculated to be $0.79,2.4,1.61$, and 0.67 , respectively. The biological reference points were calculated as $F_{\text {opt }}=0.395 ; F_{\text {lim }}=0.53$ and $E_{\text {opt }}=0.333$, respectively. The length where the maximum yield can be obtained $\left(L_{\text {opt }}\right)$ was found as $22.3 \mathrm{~cm} \mathrm{TL}$. The results showed that S.solea is under the influence of excessive fishing pressure in the Sea of Marmara.
\end{abstract}

Keywords: Common sole, Length-weight relationship, Population parameters, Sexual maturity, Excessive fishing pressure

Marmara Denizi'nde Solea solea' nın (Linnaeus, 1758) Yaş, Büyüme ve Üreme Özellikleri

Özet

Bu çalışmada Dil Balığı, Solea solea türünün Marmara Denizi'ndeki boy-ağırlık ilişkisi, yaş, büyüme ve ölüm parametreleri ve üreme biyolojisi ele alınmıştır. Örneklemeler 34 istasyondan Mart 2017 ile Aralık 2018 arasında dip trolü ile gerçekleştirilmiştir. Boy-ağılık ilişkisi $\mathrm{W}=0,0082 \times \mathrm{TL}^{3.01}$ olarak hesaplanmışıtır. Bireyler 1 ile 5 yaş aralığında dağılım göstermiştir. Von Bertalanffy büyüme parametreleri $\mathrm{L}_{\infty}=34,56 \mathrm{~cm}, \mathrm{~K}=0,48 \mathrm{y}^{-1}$, and $\mathrm{t}_{0}=-0,01 \mathrm{y}$ şeklinde hesaplanmıştır. İlk eşeysel olgunluk boyu 21.9 cm TL tespit edilmiş̧ir. Eylül'den Nisan'a kadar geniş bir üreme periyodu tespit edilmiştir. Doğal ölüm oranı $(\mathrm{M})$, toplam ölüm oranı $(\mathrm{Z})$, balıkçılık ölümü $(\mathrm{F})$ ve sömürülme oranı sırasıyla $0,79,2,4,1,61$ ve 0,67 olarak belirlenmiştir. Biyolojik referans noktaları sırasıyla $F_{\text {opt }}=0,395 ; F_{\text {lim }}=0.53$ ve $E_{\text {opt }}=0,333$ olarak hesaplanmıştır. En yüksek ürünün elde edilebileceği en uygun boy $\left(L_{\mathrm{opt}}\right) 22,3 \mathrm{~cm}$ TL bulunmuştur. Sonuçlar Dil Balığı'nın Marmara Denizi’nde aşırı avcılık etkisinde olduğunu göstermektedir.

Anahtar Kelimeler: Dil Balığı, Boy-ağırlık ilişkisi, Populasyon Parametreleri, Eşeysel olgunluk, Aşırı av baskısı

\section{INTRODUCTION}

Common sole, Solea solea (Linnaeus, 1758), is one of the commercially important members of the Soleidea family. In Turkey, the species distributed in the Black Sea, Marmara Sea, Aegean Sea, and Norteastern Mediterranean coasts (Mater et al., 2003). Globally, distribution ranges from Eastern Atlantic to the western Black Sea (Froese and Pauly, 2007). It can grow up to $70 \mathrm{~cm}$ tall and 26 years old. It generally lives on sandy and muddy grounds and at depths of 0-150 m (Froese and Pauly, 2007).

The scientific knowledge on the common sole has been published in various aspects. The feeding ecology and diet (Molinero and Flos; 1992; Cabral, 2000; Ende et al., 2018), the early life ecology (Le Pape et al., 2007; Parma et al., 2013; Di Pane et al., 2020); culture potential (Imsland et al., 2003; Avella et al., 2011); genetic (Ferraresso et al., 2016; Deconinck et al., 2020) and physiology (Davoodi and Claireaux 2007; Frapiccini et al., 2018) of the common sole have been studied by several authors. The previous studies have been centered on the length-weight relationship of common sole (Djbali et 
al., 1993; Deniel, 1990; Ramos, 1982; Girardin et al, 1986; Costa, 1990; Vianet et al., 1989; Jennings et al., 1998; Campillo, 1992; De Veen, 1976; Koutrakis and Tsikliras, 2003; Vianet et al., 1989; Duncker, 1923; Dorel, 1986; Deniel, 1984; Coull et al., 1989; Demirel and Dalkara, 2012; Hoşsucu et al.,1992; Özaydın et al., 2007; Kınacıgil et al., 2008; Gökçe et al., 2010; Türkmen, 2003; Bök et al., 2011). Also, reproduction biology was studied (Muus and Nielsen, 1999; Quéro et al., 1986; De Veen, 1976, Oral, 1996). Studies on the population parameters of the species in Turkey are insufficiant. Growth parameters were studied by Türkmen (2003) in Iskenderun Bay (Northeastern Mediterranean), Hoşsucu et al. (1999), and Cerim and Ateş (2020) in the Aegean Sea.

Previous studies on growth parameters and reproduction in the study area were limited to in a single study (Oral, 1996). To our knowledge, this is the first study on the first sexual maturity length of common sole in the Sea of Marmara. The goal of this paper is to present detailed and up-to-date information on the age, growth, mortality, and reproduction biology of the common sole in the Sea of Marmara. Due to the stock status of the economical demersal fish species which has under high fishing pressure need to be monitored continuously, we want to reveal useful data for fisheries management authority.

\section{MATERIAL AND METHOD}

The samples were collected between March 2017 and December 2018 at 34 stations located in three different depth contours $(20-50,50-100,100-200)$ from the Sea of Marmara (Figure 1). Samplings were conducted with bottom trawl which has MEDIT's standards, at a speed of 3 miles and $0.5 \mathrm{~h}$ duration. The catch-per-unit-effort (CPUE) values $\left(\mathrm{kg} \mathrm{h}^{-1}\right)$ were calculated as being the catchweight $(\mathrm{Cw})$ divided by the swept area (a) and for each haul and the mean values were computed based on depths (Sparre and Venema, 1998).

$$
C P U E=\frac{\sum C i / N h}{\sum t / N h}
$$

where ' $\mathrm{Ci}^{\prime}$ is the catch amount in $\mathrm{N}$ or $\mathrm{W}(\mathrm{kg})$ for species $\mathrm{i}$; ' $\mathrm{Nh}$ ', is the number of hauls, and ' $\mathrm{t}$ ' is haul duration in hours ' $\mathrm{h}$ '.

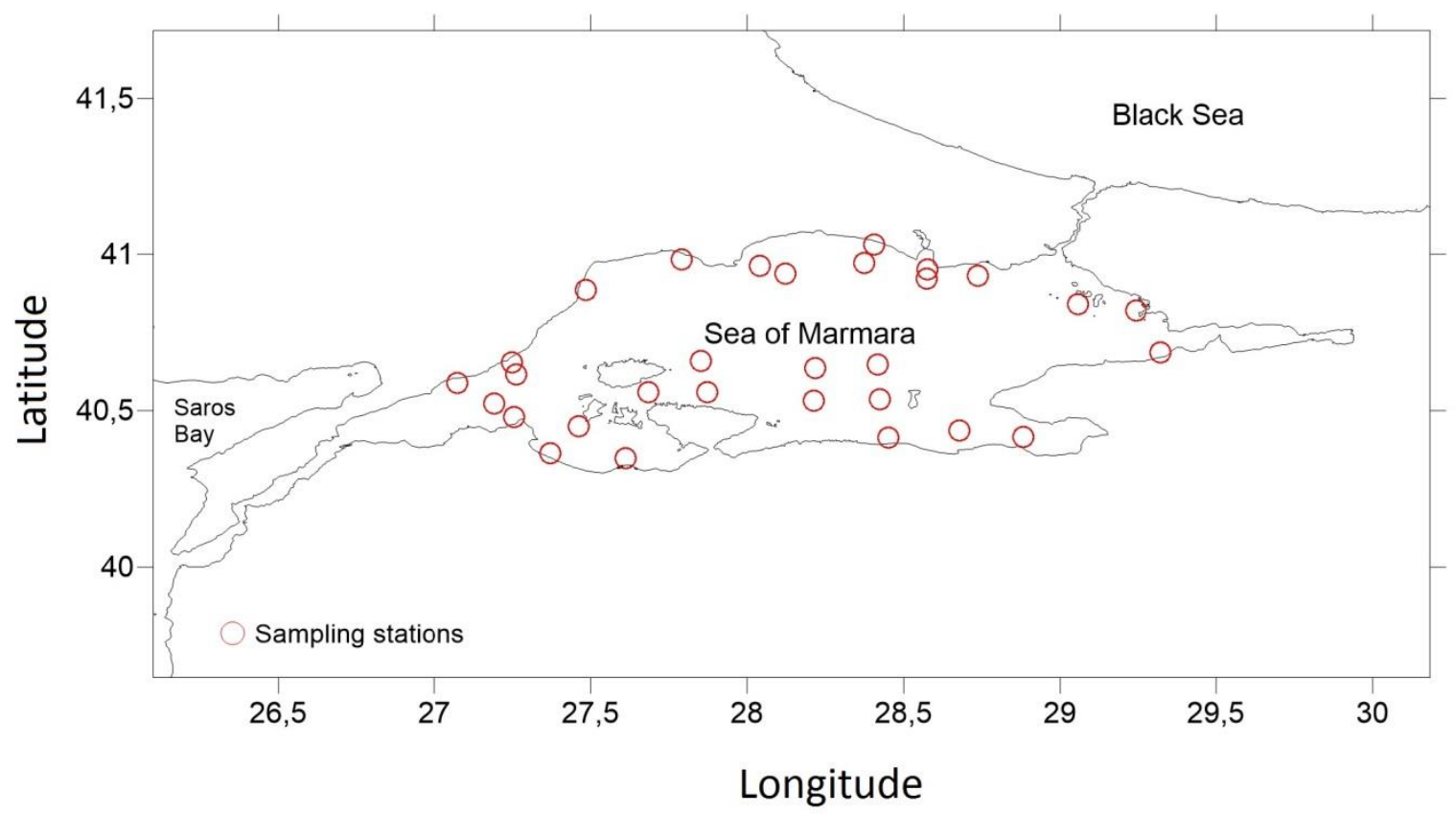

Figure 1. Sampling stations in the Sea of Marmara 
The total length (TL) of the species was measured with the nearest $0.1 \mathrm{~cm}$ precision ruler, and total weight $(\mathrm{W})$ was measured with $0.01 \mathrm{~g}$ precision balance. The length-weight relationship parameters were calculated using Le Cren (1951)'s formula

$W=a \times T L^{b}$

where $\mathrm{W}$ is the total weight ( $\mathrm{g}$ ) and TL is the total length $(\mathrm{cm}), a$ and $b$ are regression parameters. The growth type was identified according to the equation (Sokal and Rohlf, 1987):

$t s=(b-3) / S E(b)$

where ts is $t$-test value, $\mathrm{b}$ is the slope, and $\mathrm{SE}(\mathrm{b})$ is the standard error of the slope. A significant difference of $b$ values from 3, which represent isometric growth, was examined with the $t$-test (Pauly, 1993).

Sagittal otoliths were used for age determination. Growth parameters were estimated using the von Bertalanffy growth equation:

$L t=L_{\infty}\left[1-\exp \left(k\left(t-t_{0}\right)\right)\right]$

where $L(t)$ is the length at age, $L_{\infty}$ is the asymptotic length, $K$ is the growth factor, and $t_{0}$ is the theoretical age when the size of fish is zero. Growth parameters were estimated using the FISAT II program package (Gayanilo et al., 2005). The $\phi$ growth performance index was calculated as follows;

$\phi=\log K+2 \times \log L_{\infty}$

Total mortality (Z) was found using the length converted catch curve (Pauly, 1984). Natural mortality (M) was determined using Pauly's (1980) formula,

$\log (M)=(-0.0066)-0.279 \times \log (L)+0.6543 \times \log (K)+0.4634 \times \log (T)$

Fishing mortality $\left(\mathrm{F}_{\text {curr }}\right)$ was calculated using the following formula

$F_{\text {curr }}=Z-M$

The exploitation rate $\left(\mathrm{E}_{\text {curr }}\right)$ was obtained using the formula

$E_{\text {curr }}=F_{\text {curr }} / Z$

For comparison and interpretation of calculated mortality and exploitation rates, three reference points were calculated, which were the optimum fishing mortality $\left(F_{\text {opt }}\right)$, fishing mortality limit reference point $\left(F_{\mathrm{lim}}\right)$ and optimum exploitation rate $\left(E_{\mathrm{opt}}\right)$ according to Patterson (1992), Gulland (1971) and Frose et al. (2008), respectively.

$$
\begin{aligned}
& F_{\mathrm{opt}}=0.5 M \\
& F_{\text {lim }}=(2 M) 3^{-1}(\text { Patterson, 1992) } \\
& E_{\text {opt }}=F_{\text {opt }} .\left(M+F_{\text {opt }}\right)^{-1}(\text { Gulland, 1971) }
\end{aligned}
$$

Besides, the length where the maximum yield can be obtained $\left(L_{\mathrm{opt}}\right)$ was calculated.

$L_{\text {opt }}=3 L_{\infty} .\left(3+\left(M . K^{-1}\right)\right)^{-1}$ (Frose et al., 2008)

Stages of maturity were determined by Holden and Raitt (1974): immature, maturing, ripening, ripe, and spent. The gonadosomatic index (GSI) was calculated using the formula developed by Gibson and Ezzi (1980):

GSI $=($ Gonad weight $/($ Body weight - Gonad weight $)) \times 100$

The length at first maturity $\left(\mathrm{L}_{50}\right)$ was estimated by fitting a logistic function using the Newton algorithm which is defined as:

$P(1)=1 / 1+e-(a+b 1)$

where $\mathrm{P}(1)$ was the proportion of mature specimens at length 1 , and $\mathrm{a}$ and $\mathrm{b}$ are the parameters of the logistic equation (Piñeiro and Saínza, 2003).

\section{RESULTS}

A total of 80 S.solea individual was evaluated for analyses. 65 of the 80 individuals (84\%) were determined as female and the remaining 15 of them were male (16\%). The sex ratio was calculated as 1:0.2 in favor of females. Total length values were varied between 9.0 and $32.0 \mathrm{~cm}$ TL, with a mean of $23.81 \pm 4.44 \mathrm{~cm} \mathrm{TL}$. The total weight of the individuals was ranged from 7.56 to $319.62 \mathrm{~g}$, with a mean of $126.02 \pm 64.4 \mathrm{~g}$ (Table 1). The length composition and length-frequency distribution of the individuals are shown in Figures 2 and 3. The highest represented length group was determined as 22 $\mathrm{cm}$ TL for males and $27 \mathrm{~cm}$ TL for females. The mean CPUE value was calculated as $0.1 \mathrm{~kg} \mathrm{~h}^{-1}$. According to depth contours $(20-50 \mathrm{~m}, 50-100 \mathrm{~m}, 100-200 \mathrm{~m})$ the CPUE values were determined as $0.11 \mathrm{~kg} \mathrm{~h}^{-1}, 0.09 \mathrm{~kg} \mathrm{~h}^{-1}$ and $0.07 \mathrm{~kg} \mathrm{~h}^{-1}$, respectively. 
Table 1. Length-weight parameters according to the sex of S.solea in the Sea of Marmara

\begin{tabular}{lccccc}
\hline \multirow{2}{*}{ Sex } & \multirow{2}{*}{$\mathbf{N}$} & \multicolumn{2}{c}{ Length distribution $(\mathbf{c m})$} & \multicolumn{2}{c}{ Weight distribution (g) } \\
\cline { 3 - 6 } & & Min-Max & Mean \pm se & Min-Max & Mean \\
\hline Female & 65 & $10.8-31.5$ & $25.74 \pm 3.83$ & $11.45-300.83$ & $157.25 \pm 67.14$ \\
Male & 15 & $17.5-27$ & $23.17 \pm 2.77$ & $46.94-163.30$ & $104.92 \pm 33.5$ \\
Combined sexes & 80 & $9-32$ & $23.81 \pm 4.44$ & $7.56-319.62$ & $126.02 \pm 64.4$ \\
\hline \hline
\end{tabular}

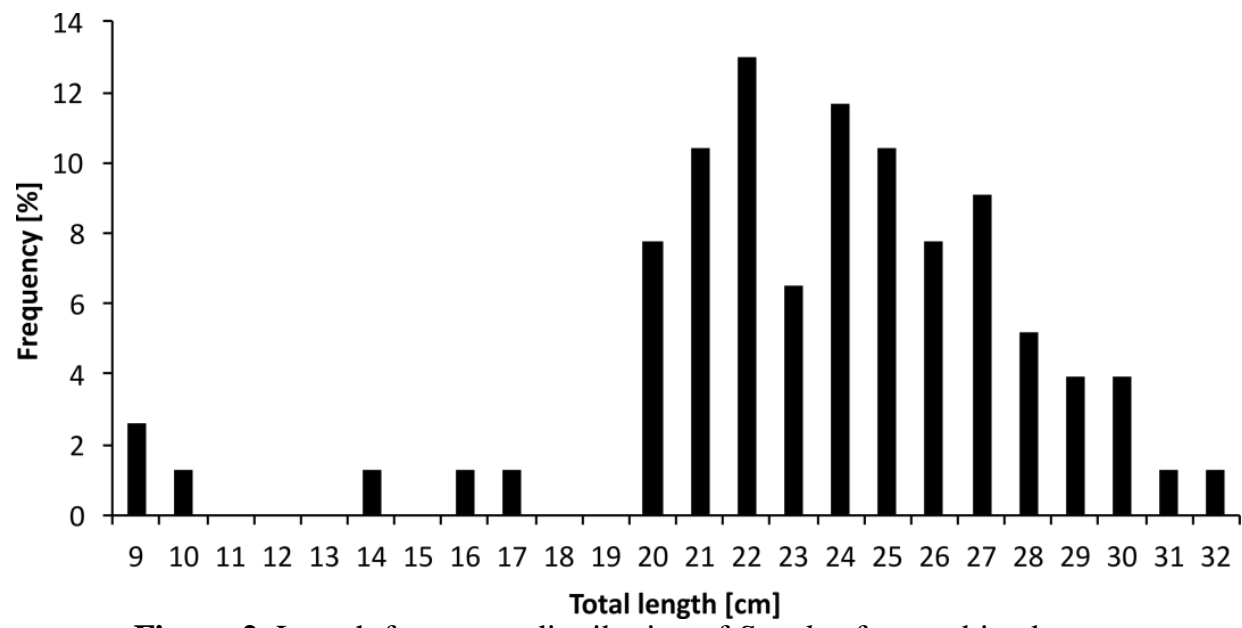

Figure 2. Length frequency distribution of $S$. solea for combined sexes

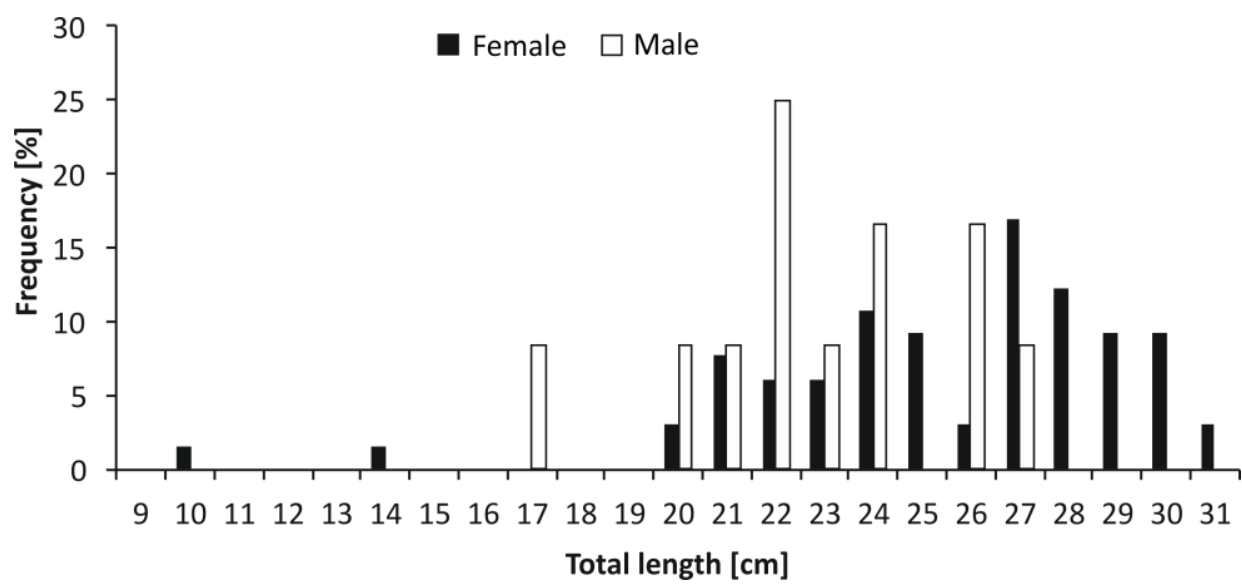

Figure 3. Length frequency distribution of female and male of $S$. solea

The relationship between the total length (L) and weight (W) of S.solea was calculated as $\mathrm{W}=0.0082 \times \mathrm{L}^{3.01}\left(\mathrm{R}^{2}=0.96\right)$ for both sexes. According to $t$-test values, common sole showed isometric growth ( $p>0.05$ ). GSI values of the individuals were ranged from 0.01 and 2.19. The GSI values of the females were differed via months in 2017 and 2018 (Figure 4). The maximum GSI for females was determined in September and December in 2017 and April and October in 2018, and the minimum GSI was found on August for both 2017 and 2018. Mature gonads of females were encountered from September to January in 2017, April 2018, and September to December 2018. Whereas, the mature gonads of males were found only in September 2017 and April in 2018. According to GSI values and maturity stages for both years, the extended spawning period occurred from September to April. Besides, spawning was peaked in two periods, autumn (September-December) and spring (April) (Figure 4). The first sexual maturity length for female individuals was determined as $L_{50}=21.9 \mathrm{~cm}$ (Figure 5). 


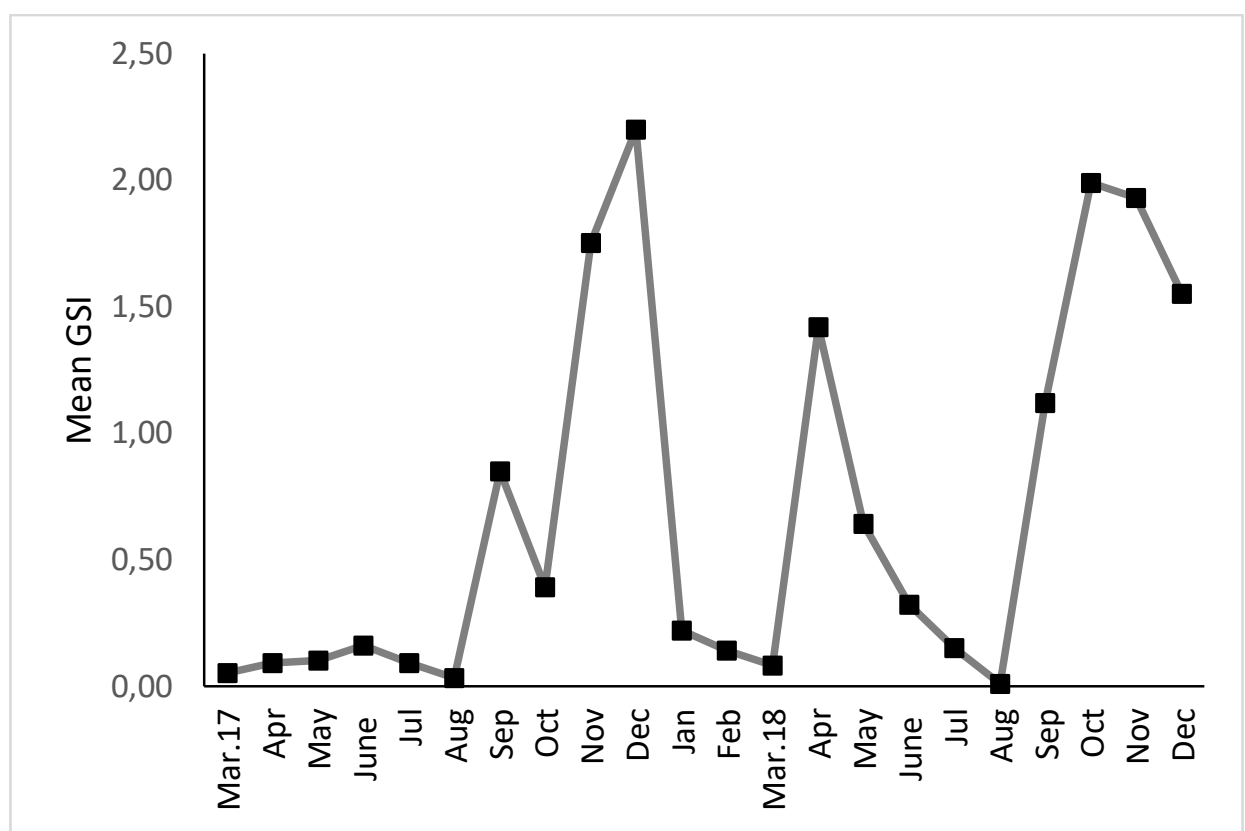

Figure 4. Monthly variation of Gonadosomatic index of female Solea solea

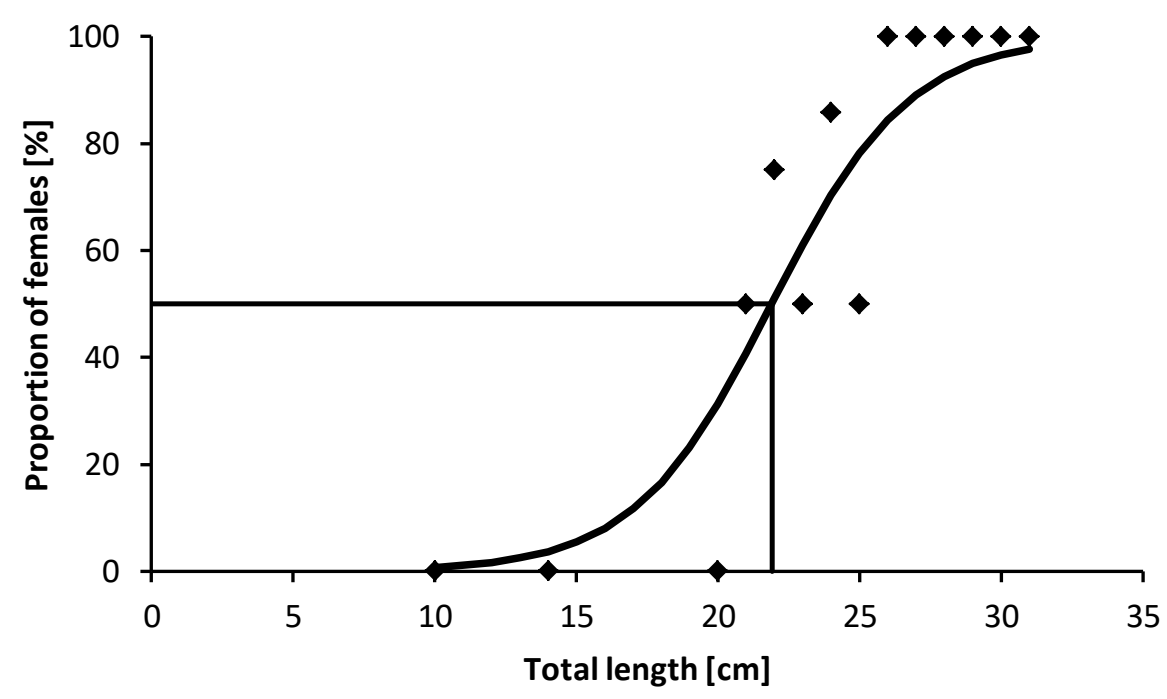

Figure 5. The first reproductive length $\left(\mathrm{L}_{50}\right)$ of S. solea female individuals.

It was determined that the age distribution was ranged from 1 and 5 (Table 3). The asymptotic length $\left(\mathrm{L}_{\infty}\right)$, growth coefficient $(\mathrm{K})$, and prenatal age $\left(\mathrm{t}_{0}\right)$ were calculated as $34.56 \mathrm{~cm} \mathrm{TL}, 0.48 \mathrm{y}^{-1}$, and $-0.01 \mathrm{y}$, respectively. (Figure 6 ). The total mortality $(\mathrm{Z})$ was calculated as 2.4 . The natural mortality $(M)$ and fishing mortality $\left(\mathrm{F}_{\text {curr }}\right)$ were detected as 0.79 and 1.61 , respectively. The exploitation rate $\left(\mathrm{E}_{\text {curr }}\right)$ was found as 0.67 . The biological reference points were calculated as $F_{\text {opt }}=0.395 ; F_{\text {lim }}=0.53$ and $E_{\text {opt }}=0.333$, respectively. The length where the maximum yield can be obtained $\left(L_{\text {opt }}\right)$ was found as $22.3 \mathrm{~cm}$ TL. 
Table 2. The total length-age key of S.solea individuals

\begin{tabular}{rcc}
\hline \hline Ages & Min- Max length & Mean length \\
\hline 1 & $9-10.8$ & $9.6 \pm 0.6$ \\
2 & $17.5-24.5$ & $22.03 \pm 0.4$ \\
3 & $25-29$ & $26.54 \pm 0.39$ \\
4 & 28 & 28 \\
5 & $30.5-32$ & $31.33 \pm 0.44$ \\
\hline \hline
\end{tabular}

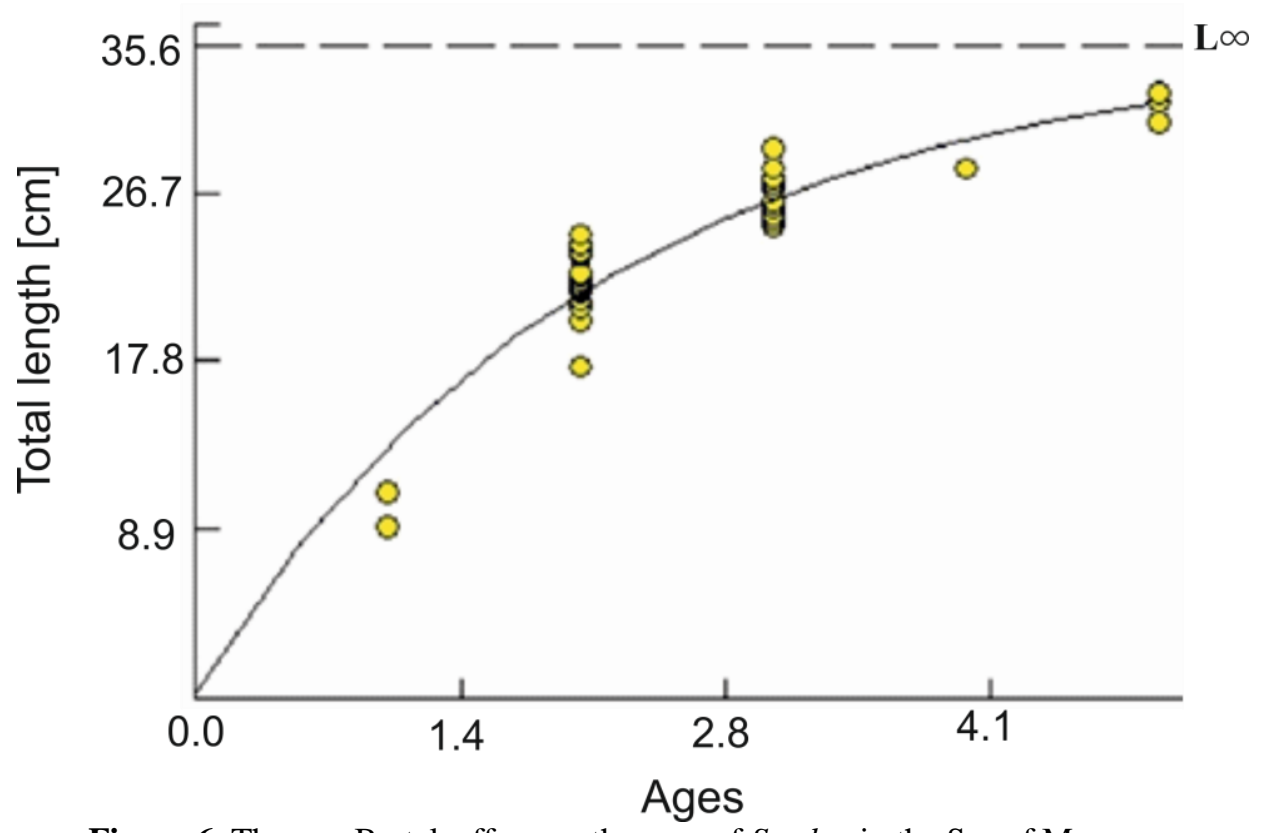

Figure 6. The von Bertalanffy growth curve of S. solea in the Sea of Marmara.

\section{DISCUSSION}

Although detailed and outnumbering sampling, collected individual number of common sole was observed low. On the other hand, fishing mortality was calculated as 1.61. This value was observed as the highest estimated fishing mortality value among 10 commercially important demersal fish species (Merluccius merluccius, Merlangius merlangus, Chelidonichthys lucernus, Lophius budegassa, Zeus faber, Mullus surmuletus, Mullus barbatus, Trigla lyra, Citharus linguatula) which undertaken in this project in the Sea of Marmara. The CPUE values showed that $74 \%$ of the total catch of common sole was sampled at the stations located lower than $100 \mathrm{~m}$ depths. Trawl fisheries are restricted in the Sea of Marmara. Therefore, the reason of the low CPUE can be thought of as a result of high fishing pressure that originated from beam trawls in the Sea of Marmara. According to fisheries statistics in Turkey, beam trawl vessel number has been increased from 297 to 634 in the last 8 years (TUIK, 2020). Although the target species of beam trawls in the Sea of Marmara is deep water rose shrimp (Parapenaeus longirostris), it may have a large fishing pressure on other demersal fish species as well.

The sex ratio in this study was far from expected value. Higher female number may arise from the small number of sampling. According to Table 3, it can be seen that the growth type of common sole is mostly as isometric and positive allometric. In this study, an isometric growth was observed. 
Table 3. The length-weight relationship parameters of S.solea from different regions.

\begin{tabular}{|c|c|c|c|c|c|c|}
\hline Researchers & Region & Sex & $\bar{a}$ & $\bar{b}$ & $\boldsymbol{R}^{2}$ & Growth type \\
\hline Duncker 1923 & North Sea & $\mathrm{F}+\mathrm{M}$ & 0.007 & 3.10 & 0.954 & \\
\hline \multirow{2}{*}{ De Veen 1976} & \multirow{2}{*}{ Netherlands } & $\mathrm{M}$ & 0.008 & 3.00 & & \\
\hline & & $\mathrm{F}$ & 0.009 & 3.00 & & \\
\hline Deniel 1984 & Douarnenez Bay, Britain & & 0.005 & 3.21 & & \\
\hline Bedford et al. 1986 & England & $\mathrm{F}+\mathrm{M}$ & 0.008 & 3.07 & & \\
\hline \multirow{2}{*}{ Dorel 1986} & Biscay Bay & & 0.005 & 3.18 & 0.998 & \\
\hline & North and south Bay, France & & 0.004 & 3.26 & 1.000 & \\
\hline Coull et al. 1989 & Moray Firth, Alman Bight and Clyde, Scotland & & 0.004 & 3.31 & & A+ \\
\hline Vianet et al. 1989 & Lion Bay & $\mathrm{F}+\mathrm{M}$ & 0.006 & 3.04 & 0.980 & \\
\hline Hoşsucu 1992 & Aegean Sea & $\mathrm{F}+\mathrm{M}$ & 0.005 & 3.14 & & \\
\hline \multirow{2}{*}{ Campillo 1992} & \multirow{2}{*}{ Lion Bay } & $\mathrm{M}$ & 0.011 & 2.94 & & \\
\hline & & $\mathrm{F}$ & 0.009 & 2.99 & & \\
\hline Djabali et al. 1993 & Adriatic Sea & & 0.007 & 3.00 & & \\
\hline Oral, 1996 & Sea of Marmara & $\mathrm{F}+\mathrm{M}$ & 0.0013 & 3.62 & & \\
\hline Koutrakis and Tsikliras 2003 & Porto-Lagos, Aegean Sea & juvenil & 0.010 & 3.00 & 0.988 & \\
\hline \multirow{2}{*}{ Turkmen 2003} & \multirow{2}{*}{ İskenderun Bay } & $\mathrm{M}$ & 0.012 & 2.99 & 0.922 & $\mathrm{I}$ \\
\hline & & $\mathrm{F}$ & 0.009 & 3.08 & 0.947 & $\mathrm{I}$ \\
\hline Mendes et al. 2004 & Nazaré to St André, Portugal & $\mathrm{F}+\mathrm{M}$ & 0.007 & 3.09 & 0.953 & \\
\hline Dulčić and Glamuzina 2006 & Mirna, North Adriatic, Croatia & $\mathrm{F}+\mathrm{M}$ & 0.002 & 3.45 & 0.946 & $\mathrm{~A}+$ \\
\hline Özaydın et al. 2007 & Aegean Sea & $\mathrm{F}+\mathrm{M}$ & 0.002 & 3.20 & & \\
\hline Kınacigil et al. 2008 & Aegean Sea & $\mathrm{F}+\mathrm{M}$ & 0.002 & 3.36 & & $\mathrm{~A}+$ \\
\hline Veiga et al. 2009 & Algarve & $\mathrm{F}+\mathrm{M}$ & 0.008 & 3.08 & 0.969 & $\mathrm{I}$ \\
\hline Gökçe et al. 2010 & İskenderun Bay & juvenil & 0.049 & 2.35 & 0.980 & \\
\hline Bok et al. 2011 & Sea of Marmara & juvenil & 0.004 & 3.17 & 0.928 & I \\
\hline Demirel and Dalkara 2012 & Sea of Marmara & $\mathrm{F}+\mathrm{M}$ & 0.006 & 3.06 & 0.853 & $\mathrm{I}$ \\
\hline Maci et al. 2012 & Acquatina, Lecce, & $\mathrm{F}+\mathrm{M}$ & 0.011 & 3.06 & 0.981 & \\
\hline Crec'hriou et al. 2013 & Catalan coasts, France & $\mathrm{F}+\mathrm{M}$ & 0.010 & 2.96 & 0.932 & \\
\hline Froese and Sampang 2013 & North Sea & $\mathrm{F}+\mathrm{M}$ & 0.005 & 3.20 & 0.975 & \\
\hline Cerim and Ateş, 2020 & Aegean Sea & $\mathrm{F}+\mathrm{M}$ & 0.008 & 3.064 & 0.99 & $\mathrm{~A}+$ \\
\hline This study & Sea of Marmara & $\mathrm{F}+\mathrm{M}$ & 0.0082 & 3.01 & 0.96 & $\mathrm{I}$ \\
\hline
\end{tabular}

A+ : positive allometry, A- : negative allometry, I: isometry 
According to GSI values and maturity stages, an extended spawning period occurred from September to April. An extended spawning duration for common sole was observed from the studies conducted by Quéro et al. (1986) and Oral (1996). A relatively shorter spawning period was seen in some studies (Table 4). These variations may be stemmed from geographical differences, sampling times, and sampling types. On the other hand, Cerim and Ateş (2019) were found several batches in the spawning season of common sole and stated that partial spawning is a common situation. They observed different peaks in dense spawning times between years. These results coincided with ours. Although it varied by years, spawning peaked in autumn and at the end of the winter. They interpreted that this variation can be closely related to temperature variations of seawater between years. Different spawning peaks in a year were also observed by Anguis and Canavate (2005) for Senegal sole (Solea senegalensis) in the south Atlantic coast of Iberia. Devauchelle et al. (1987) were stated that the common sole spawns between 8 and $12.5^{\circ} \mathrm{C}$ in a natural environment. According to the mean deep water temperature values measured in our study, higher temperature values were observed in 2018. Thus, it can be said that the bottom water temperature is the main determinant for the spawning duration of the common sole.

Table 4. Reproductive parameters of S.solea from different regions.

\begin{tabular}{|c|c|c|c|c|}
\hline Author & Area & Sex & $\begin{array}{l}\text { Reproductive } \\
\text { time }\end{array}$ & $\begin{array}{l}\mathbf{L m} \\
(\mathrm{cm})\end{array}$ \\
\hline \multirow[t]{2}{*}{ De Veen 1976} & Netherlands & $\mathrm{F}$ & & 27.0 \\
\hline & & $\mathrm{F}$ & & 30.0 \\
\hline \multirow[t]{3}{*}{ Dorel 1986} & Bay of Biscay, France & & & 22.0 \\
\hline & Bay of Biscay, France & $\mathrm{F}$ & & 31.0 \\
\hline & $\begin{array}{l}\text { East and west channel, } \\
\text { France }\end{array}$ & & & 28.0 \\
\hline \multirow[t]{2}{*}{ Quéro et al. 1986} & Bay of Biscay & & December-May & \\
\hline & Netherlands & & April-June & \\
\hline Deniel 1990 & Douarnenez Bay, France & & & 32.0 \\
\hline $\begin{array}{lll}\begin{array}{l}\text { Rijnsdorp } \\
1997\end{array} & \text { and } & \text { Vethaak } \\
\end{array}$ & North Sea, England & & & 26.0 \\
\hline $\begin{array}{ll}\begin{array}{l}\text { Rijnsdorp and } \\
1997\end{array} & \\
\end{array}$ & Germany & & March-June & \\
\hline Jennings et al. 1998 & North Sea, England & & & 24.8 \\
\hline Muus and Nielsen 1999 & South England & & May-June & \\
\hline Oral 1996 & Sea of Marmara & & $\begin{array}{l}\text { December- } \\
\text { February }\end{array}$ & \\
\hline \multirow[t]{2}{*}{ Vasilakopoulos et al. 2011} & Irish Sea & $\mathrm{M}$ & May-June & \\
\hline & Skagerrak and Kattegat & & April-June & \\
\hline \multirow[t]{2}{*}{ Froese and Sampang 2013} & North Sea & $\mathrm{M}$ & & 18.8 \\
\hline & Trevose, England & $\mathrm{F}+\mathrm{M}$ & & 18.8 \\
\hline This study & Sea of Marmara & $\mathrm{F}$ & Autumn- Spring & 21.9 \\
\hline
\end{tabular}

The first sexual maturity length $\left(\mathrm{L}_{\mathrm{m}}\right)$ of the common sole was determined as $21.9 \mathrm{~cm}$ TL. When compared the results with the findings of studies outlined in Table 4, it can be seen that the sexual maturity length of common sole occurred at smaller lengths. The smaller $\mathrm{L}_{50}$ values may arise from various factors. One of the most possible explanations may be explained with the probabilistic maturation reaction norm (PMRN). According to PMRN the $\mathrm{L}_{50}$ can vary abide by the length interval of the sampling. As the length group gets smaller, the value of $\mathrm{L}_{50}$ gets smaller (Rijndorp, 1989; Horwood, 1993; Sampson and Al-Jufaily, 1999). Also, Morgan (2003) was stated that due to the high fishing pressure length range of the stock becomes smaller. A $23 \mathrm{~cm}$ TL mean length in our study support this hypothesis. Besides, Shuozeng (1995) stated that males can reach sexual maturity earlier than females. The study of Froese and Sampang (2013) was convinced this finding, whereas the low male individual number in our study enable us to ignore this situation. Additionally, Pauly (1994) identified that $\mathrm{L}_{50}$ appears to increase with latitude for many flatfish species. Contrary to this, 
Horwood (1993) found that $\mathrm{L}_{50}$ of the common sole was higher in the southern latitude than northern. When the results of $L_{50}$ values of the studies summarized in Table 4 were investigated, higher $L_{50}$ values were seen although carried out in more northern areas. So our finding supported Horwood (1993)'s findings.

When the age length key of this study was examined, a great majority of individuals (85\%) were formed between 0 and 3 age class. On the other hand, the maximum age of stock was observed as 5 years. The maximum age was determined as 9 years by Cerim and Ates (2020) in the southern Aegean Sea, 8 years by Turkmen (2003) in Iskenderun Bay, like 7 years by Ramos (1982) in the western Mediterranean, and also 7 years by Oral (1996) in the Sea of Marmara, as 6 years by Stergiou et al. (1997) in the Amvrakikos, Greece. Hossucu et al. (1999) found the maximum age as 5 years in the Izmir Bay, the Aegean Sea, where area of overexploited stocks. The sampling method, fishing pressure, food availability, and competition variations between the studies and areas may cause the varied age distributions.

The asymptotic length in our study was estimated as $34.56 \mathrm{~cm}$ TL. This result is compatible with the maximum length $(32 \mathrm{~cm} \mathrm{TL})$ in the data set. Relatively lower estimated asymptotic length caused a higher $\mathrm{K}$ value. As can be seen in Table 5, the $\mathrm{K}$ values showed differences between the studies. Smaller K values were calculated in some studies as Teixeira and Cabral (2010), Turkmen (2003), and Cerim and Ateş (2020), which found the maximum age higher than 8 . The lower $\mathrm{K}$ values of these studies were highly related to the higher age class in the data set. Besides, lower values of growth parameters in our study may arise from high fishing mortality and a limited number of individuals examined. This situation was based on fishing pressure by Nash and Geffen (2015). Due to high fishing pressure tends to higher fishing mortality rates, the older age classes disappear from the stock and the age class becomes smaller. Additionally, the selectivity of the commercial fishing nets excludes 0 age group in the data set. Hence, the age interval becomes bounded and the growth parameters may calculate smaller. As can be seen in Table 5, the $\phi$ growth performance index values reported by the researchers ranged between 2.03 and 3.04. It was determined that there was no statistically significant difference between the value obtained in this study and previous studies ( $>0.05)$ (Table 5). Hence, it can be said that these parameters were closely related to the age length distribution of the data set. 
Table 5. Von Bertalanffy growth parameters of S.solea from different regions.

\begin{tabular}{|c|c|c|c|c|c|c|}
\hline Author & Area & Sex & $\mathbf{L} \infty$ & $\begin{array}{c}\mathbf{K} \\
\left(\text { year }^{-1}\right)\end{array}$ & $\mathbf{t}_{0}($ year $)$ & $\varnothing$ \\
\hline \multirow[t]{2}{*}{ Ramos 1982} & \multirow{2}{*}{$\begin{array}{l}\text { Castellon coast, } \\
\text { Spain }\end{array}$} & $\mathrm{M}$ & 38.8 & 0.240 & -1.09 & 2.56 \\
\hline & & $\mathrm{F}$ & 46.4 & 0.220 & -0.75 & 2.68 \\
\hline Froglia and Giannetti 1985 & Adriatic Italy & & 38.3 & 0.492 & -3.57 & 2.86 \\
\hline \multirow[t]{2}{*}{ Froglia and Giannetti 1986} & \multirow[t]{2}{*}{ Adriatic Italy } & $M$ & 23.2 & 0.828 & -1.66 & 2.65 \\
\hline & & $\mathrm{F}$ & 37.9 & 0.504 & -5.36 & 2.86 \\
\hline \multirow[t]{2}{*}{ Girardin et al. 1986} & \multirow[t]{2}{*}{ Lion Bay } & $\mathrm{M}$ & 53.8 & 0.160 & & 2.67 \\
\hline & & $\mathrm{F}$ & 47.2 & 0.274 & & 2.79 \\
\hline Wurtz and Matricardi 1986 & Tiran Sea & & 35.8 & 0.406 & & 2.72 \\
\hline Vianet et al. 1989 & Lion Bay & & 48.8 & 0.240 & -0.77 & 2.76 \\
\hline Costa 1990 & $\begin{array}{l}\text { Tagus Bay, } \\
\text { Portugal }\end{array}$ & & 48.3 & 0.470 & & 3.04 \\
\hline \multirow[t]{2}{*}{ Deniel 1990} & \multirow{2}{*}{$\begin{array}{l}\text { Douarnenez Bay } \\
\text { Britain }\end{array}$} & $\mathrm{M}$ & 42.4 & 0.397 & 0.09 & 2.85 \\
\hline & & $\mathrm{F}$ & 48.2 & 0.329 & 0.08 & 2.88 \\
\hline Erzini 1991 & North Sea & & 37.4 & 0.310 & & 2.64 \\
\hline Djabali et al. 1993 & Adriatic Italy & & 40.1 & 0.680 & & 3.04 \\
\hline Oral 1996 & Sea of Marmara & & 37.1 & 0.100 & -3.267 & 2.27 \\
\hline Stergiou et al. 1997 & $\begin{array}{l}\text { Amvrakikos Bay, } \\
\text { Greece }\end{array}$ & & 35.6 & 0.380 & -0.41 & 2.67 \\
\hline Jennings 1998 & Kelt Sea, England & & 49.8 & 0.130 & & 2.51 \\
\hline \multirow[t]{2}{*}{ Hossucu et al. 1999} & \multirow[t]{2}{*}{ Aegean Sea } & $\mathrm{M}$ & 30.0 & 0.330 & -1.04 & 2.50 \\
\hline & & $\mathrm{F}$ & 42.5 & 0.170 & -1.96 & 2.49 \\
\hline \multirow[t]{2}{*}{ Turkmen 2003} & \multirow[t]{2}{*}{ İskenderun Bay } & $M$ & 26.0 & 0.221 & -1.31 & 2.17 \\
\hline & & $\mathrm{F}$ & 29.9 & 0.181 & -1.55 & 2.21 \\
\hline \multirow[t]{2}{*}{ Teixeira and Cabral 2010} & \multirow[t]{2}{*}{ Portugal } & $\mathrm{M}$ & 45.7 & 0.210 & -1.57 & 2.64 \\
\hline & & $\mathrm{F}$ & 52.1 & 0.230 & -0.11 & 2.80 \\
\hline Colloca et al. 2013 & Adriatic Sea, Italy & & 39.6 & 0.440 & -0.46 & 2.84 \\
\hline Froese and Sampang 2013 & North Sea & & 40.0 & 0.148 & -3.00 & 2.37 \\
\hline Gabr 2015 & $\begin{array}{l}\text { Bardawil Bay, } \\
\text { Egypt, }\end{array}$ & & 31.1 & 0.330 & -1.51 & 2.47 \\
\hline \multirow[t]{3}{*}{ Cerim and Ateş, 2020} & \multirow[t]{3}{*}{ Aegean Sea } & $\mathrm{F}+\mathrm{M}$ & $\begin{array}{l}33.9 \\
5 \\
\end{array}$ & 0.208 & -0.032 & 2.54 \\
\hline & & $\mathrm{F}$ & $\begin{array}{l}31.9 \\
8\end{array}$ & 0.236 & -0.037 & 2.41 \\
\hline & & $\mathrm{M}$ & $\begin{array}{l}29.1 \\
1 \\
\end{array}$ & 0.324 & -0.030 & 2.29 \\
\hline This study & Sea of Marmara & $\mathrm{M}+\mathrm{F}$ & 34.56 & 0.48 & -0.01 & 2.76 \\
\hline
\end{tabular}

Oral (1996) sampled 523 individuals between 1992 and 1994 with beam trawl and beach seine between 5 and 90 m depths at 13 stations located in the Sea of Marmara. The sampling stations of this study and Oral's study are similar. Due to CPUE was not calculated in that study, stock status compared based on the number of individuals caught. A quite low individual number in this study clearly showed that the common sole stocks under threatened in the Sea of Marmara. Overfishing, changes in the sea the physic-chemical parameters of seawater, and wrong fisheries management applications may be a result of this problem.

Biological reference points are defined as a principal tool for fishery management strategies. Due to comparison and interpretation of the calculated mortality rates, biological refecence points reveals useful information(Zhang et al. 2017; Cerim et al., 2020). The calculated fishing mortality rate $\left(F_{\text {curr }}=1.61\right)$ in this study was relatively higher than the estimated optimum $\left(F_{\mathrm{opt}}=0.395\right)$ and limit $\left(F_{\lim }=0.53\right)$ fishing pressure. Current fishing mortality is higher than the reference points. Also, estimated optimum length $\left(L_{\mathrm{opt}}=22.3 \mathrm{~cm}\right)$ where the maximum yield can be obtained was above both $\mathrm{L}_{50}=21.3 \mathrm{~cm}$ and the minimum landing length $(20 \mathrm{~cm})$ that was determined by the Turkish Fisheries Management Authority. Fishing pressure on low sizes should be decreased to ensure a sustainable fishery. 
Consequently, after 25 years, it can be said that the stock structure has been damaged. High mortality rates and low age interval and biomass supported this result. As with many other species, the minimum landing sizes should be rearranged and fishing pressure should be decreased. Although the trawl fishery is restricted, illegal trawling is still ongoing and causes problems in the Sea of Marmara. Also, the shallower distribution of many commercial demersal fish species in the Sea of Marmara has become the target of beam trawls. The laws should be persuader and control mechanisms should be increased.

\section{ACKNOWLEDGEMENT}

This study was financially supported by TAGEM Project no: TAGEM/HAYSÜD/2014/05/01. The authors would like to thanks the crew of Yalcinoglu Fishing vessel and Murat ŞíRIN, Koray CABBAR, G. Erman UĞUR, Hasim İNCEOĞLU, Habib BAL, Ahmet ÖKTENER, G. Ali YAZICI and Güzin GÜL for their helps in the fieldwork.

\section{REFERENCES}

Anguís, V., \& Cañavate J.P. (2005). Spawning of captive Senegal sole (Solea senegalensis) under a naturally fluctuating temperature regime. Aquaculture 243, 133-145. doi:10.1016/j.aquaculture.2004.09.026

Avella, M.A., Olivotto, I., Silvi, S., Ribecco, C., Cresci, A., Cresci, F., Palermo, F., Polzonetti, A., \& Carnevali O. (2011). Use of Enterococcus faeciumto improve common sole (Solea solea) larviculture. Aquaculture 315:384e93.

Bedford, B.C., Woolner, L.E., \& Jones, B.W. (1986). Length-weight relationships for commercial fish species and conversion factors for various presentations. Ministry of Agriculture, Fisheries and Food. Directorate of Fisheries Research. Fisheries Research Data Report No. 10.

Bök, T.D., Gokturk, S.D., Kahraman, A.E., Alicli, T.Z., Acun, T., \& Ates, C. (2011). Length-weight relationships of 34 fish species from the Sea of Marmara, Turkey. Journal of Animal and Veterinary Advances, 10 (23): 3037-3042.

Cabral, H.N. (2000). Comparative feeding ecology of sympatric Solea solea and S. senegalensis, within the nursery areas of the Tagus estuary, Portugal. Journal of Fish Biology 57:1550-1562.

Campillo, A. (1992). Les pêcheries françaises de Méditeranée: synthèse des connaissances. Institut Francais de Recherche pour l'Exploitation de la Mer, France. 206 p.

Cerim, H., \& Ateş C. (2019). Reproductive Biology of Female Common Sole, Solea Solea (Linnaeus, 1758) in the Southern Aegean Sea. Acta Biologica Turcica 32 (3): 143-148.

Cerim, H., \& Ateş, C. (2020). Age, growth and length-weight relations of common sole (Solea solea Linnaeus, 1758) from Southern Aegean Sea. Aquatic Sciences and Engineering 35(2), 36-42.

Cerim, H., Soykan, O., \& Gülşahin, A. (2020). Mortality and exploitation of marbled spinefoot, Siganus rivulatus (Actinopterygii: Perciformes: Siganidae), from southern Aegean Sea small-scale fishery. ACTA ICHTHYOLOGICA ET PISCATORIA 5O(2): 183-190. DOI: 10.3750/AIEP/02841

Colloca, F., Cardinale, M., Maynou, F., Giannoulaki, M., Scarcella, G., Jenko, K., Bellido, J.M., \& Fiorentino, F. (2013). Rebuilding Mediterranean fisheries: a new paradigm for ecological sustainability. Fish and Fisheries 14: 89-109.

Costa, M.J. (1990). Age and growth studies of the sole (Solea vulgaris vulgaris (Quensel, 1806) in the Tagus estuary, Portugal). Boletim (do) Instituto Nacional de investigacao das Pescas 15:63-67.

Coull, K.A., Jermyn, A.S., Newton, A.W., Henderson, G.I., \& Hall, W.B. (1989). Length-weight relationships for 88 species of fish encountered in the North Atlantic. Scottish Fisheries Research Report, 43: 80.

Crec'hriou, R., Neveu, R., \& Lenfant, P. (2013). Length-weight relationship of main commercial fishes from the French Catalan coast. Journal of Applied Ichthyology 29:1191-1192.

Davoodi, F., \& Claireaux, G. (2007). Effects of exposure to petroleum hydrocarbons upon the metabolism of the common sole (Solea solea). Mar. Pollut. Bull. 54 (7), 928-934.

De Veen, J.F. (1976). On changes in some biological parameters in the North Sea sole (Solea solea L.). Journal du Conseil CIEM 37:60-90.

Deconinck, D., Volckaert, F.A., Hostens, K., Panicz, R., Eljasik, P., Faria, M., Monteirod, C.S.,Robbens, J., \& Derycke, S. (2020). A high-quality genetic reference database for European commercial fishes reveals substitution fraud of processed Atlantic cod (Gadus morhua) and common sole (Solea solea) at different steps in the Belgian supply chain. Food Chem. Toxicol. 111417.

Deniel, C. (1990). Comparative study of growth of flatfishes on the west coast of Brittany. J. Fish Biol. 37(1):149-166.

Demirel, N., \& Dalkara, M.E. (2012). Weight-Length relationships of 28 fish species in the Sea of Marmara. Turkish Journal of Zoology 36(6):785-791. 
Devauchelle, N., Alexandre, J.C., Le Corre, N., \& Letty, Y. (1987). Spawning of sole Solea solea in captivity. Aquaculture 66:125-147.

Di Pane, J., Gendrot, F., Giraldo, C., Marchal, P., Koubbi, P. \& Loots, C. (2020). Evaluating the histologicalbased condition of wild collected larval fish: A synthetic approach applied to common sole (Solea solea). Journal of Marine Systems 204:103309. https://doi.org/10.1016/j.jmarsys.2020.103309

Djabali, F., Mehailia, A., Koudil, M., \& Brahmi, B. (1993). Empirical equations for the estimation of natural mortality in Mediterranean teleosts. Naga: the ICLARM Quarterly 16(1):35-37.

Dorel, D. (1986). Poissons de l'Atlantique nord-est relations taille-poids. Institut Francais de Recherche pour l'Exploitation de la Mer. Nantes, France. 165 p. (in French).

Dulcic, J., \& Glamuzina, B. (2006). Length-weight relationships for selected fish species from three eastern Adriatic estuarine systems (Croatia). Journal of Applied Ichthyology 22:254-256.

Duncker, G. (1923). Korrelation zwischen Länge und Gewicht der Fische. Wissenschaftliche Meeresuntersuchungen Helgoland, 15(4):1-50 (in German).

Ende SSW, Schrama JW, \& Verreth JAJ. (2018). The influence of prey size, sediment thickness and fish size on consumption in common sole (Solea solea L.). J Appl Ichthyol 34:111-116. DOI://doi.org/10.1111/jai.13520.

Erzini, K. (1991). A compilation of data on variability in length-age in marine fishes. Fisheries Stock Assessment, Title XII, Collaborative Research Support Program, University of Rhode Island. Working paper 77, 36p.

Ferraresso, S., Bonaldo, A., Parma, L., Buonocore, F., Scapigliati, G., Gatta, P.P., Bargelloni L. (2016). Ontogenetic onset of immune-relevant genes in the common sole (Solea solea). Fish Shellfish Immunol. 57:278-92. doi:10.1016/j.fsi.2016.08.044

Frapiccini, E.; Annibaldi, A.; Betti, M.; Polidori, P.; Truzzi, C.; Marini, M. (2018). Polycyclic aromatic hydrocarbon $(\mathrm{PAH})$ accumulation in different common sole (Solea solea) tissues from the North Adriatic Sea peculiar impacted area. Mar. Pollut. Bull., 137, 61-68.

Froese, R., \& Pauly, D. (2007). Editors. FishBase version (12/2008). World Wide Web electronic

Froese, R., \& Sampang, A. (2013). Potential indicators and reference points for good environmental status of commercially exploited marine fishes and invertebrates in the German EEZ. http://oceanrep.geomar.de/22079/

Froglia, C., \& Giannetti, G. (1985). Growth of common sole Solea vulgaris quensel in the Adriatic Sea (Osteichthyes, Soleidae). Rapports Commission international Mer Méditerranean 29(8): 91-93.

Froglia, C., \& Giannetti, G.F. (1986). Remarks on rings formation in otoliths of Solea vulgaris and other flatfishes from the Adriatic Sea. FAO Fisheries Report, 345:121-122.

Gabr, M.H. (2015). Capture production and stock assessment of Solea aegyptiaca Chabanaud, 1927 (Soleidae: Pleuronectiformes) in Bardawil Lagoon, Egypt. Egyptian Journal of Aquatic Research 41 (1): 101-110. http://dx.doi.org/10.1016/j.ejar.2015.01.006

Gayanilo, F.C.Jr., Sparre, P., \& Pauly, D. (2005). FAO-ICLARM Stock Assessment Tools II (FiSAT II). Revised version. User's guide. FAO Computerized Information Series (Fisheries). No. 8, Revised version. Rome, FAO, 168 p.

Gibson, R.N., \& Ezzi I.A. (1980). The biology of the scaldfish, Arnoglossus laterna (Walbaum) on the west coast of Scotland. Journal of Fish Biology 17:565-575.

Girardin, M., Talet, A.B., Campillo, A., \& Chalabi, A. (1986). Evaluation du rendement relatif par recrue à partir de distributions de fréquences de tailles. Application à trois espèces démersales (Solea vulgaris, Phycis blennoides et Boops boops) de la Méditerranée occidentale. p. 212-220. In D. Charbonnier (ed.) Rep. 4th Tech. Consultation of the Gen. Fish. Council for the Mediterranean on stock assessment in the Balearic and Gulf of Lions statistical divisions. Sidi-Fredj, Algeria, 16-21 Nov. 1985. FAO Fisheries Report, (347).

Gökçe, G., Çekiç, M., \& Filiz, H. (2010). Length-weight relationships of marine fishes off Yumurtalık coast (İskenderun Bay), Turkey. Turkish Journal of Zoology 34:101-104.

Holden, M.J., \& Raitt D.F.S. (1974). Manual of Fisheries Science. Part 2-Methods of recource investigation and their application. FAO Fisheries Technical Papers, 115. Rev. 1., 214 p.

Horwood, J. (1993). The Bristol Channel sole (Solea solea (L.)): A fisheries case study. Advances in Marine Biology 29, 215-367.

Hoşsucu B. (1992). Research on the distribution and biological features of sole (Solea solea L.) in Izmir Bay. E. U. Journal of Fisheries 9:124-132. (in Turkish).

Hoşsucu, B., \& Çoker, T. (1997). Determination of batch fecundity in sole (Solea vulgaris Quinsel,1806) from the Izmir Bay, (in Turkish). Journal of Fisheries and Aquatic Sciences 14(1-2):13-17.

Hoşsucu, B., Kaya M., \& Taskavak, E. (1999). An investigation of growth parameters and otolith-total length relationship of Solea solea (L., 1758) (Pisces:Soleidae) in Izmir Bay. Israel Journal of Zoology 45:277287. 
Imsland, A.K., Foss, A., Conceição, L.E.C., Dinis, M.T., Delbare, D., Schram, E., Kamstra, A., Rema, P., \& White, P. (2003). A review of the culture potential of Solea solea and S. senegalensis. Rev. Fish Biol. Fish. 13:379-407.

Jennings, S., Reynolds, J.D., \& Mills, S.C. (1998). Life history correlates of responses to fisheries exploitation. Proceedings of the Royal Society B: Biological Sciences 265:333-339.

Kınacıgil, H.T., İlkyaz, A.T., Metin, G., Ulaş, A., Soykan, O., Akyol, O., \& Gurbet, R. (2008). Determination of the first sexual maturity lengths, ages and growth parameters of fish stocks of Aegean Sea in terms of fisheries managemenet. February 2008. TUBITAK PROJECT (103Y132) Final Report, 327s.

Koutrakis, E.T., \& Tsikliras, A.C. (2003). Length-weight relationships of fishes from three northern Aegean estuarine systems (Greece). Journal of Applied Ichthyology 19:258-260.

Le Cren, E.D. (1951). The length weight relationship and seasonal cycle in gonad weight and condition in the Perch (Perca fluviatilis). Journal of Animal Ecology 20(2): 201-219.

Le Pape, O., Baulier, L., Cloarec, A., Martin, J., Le Loc'h, F., \& Desaunay, Y. (2007). Habitat suitability for juvenile common sole (Solea solea, L.) in the bay of Biscay (France): a quantitative description using indicators based on epibenthic fauna. Journal of Sea Research 57, 126-136.

Maci, S., Longo, E., \& Basset, A. (2009). Length-weight relationships for 24 selected fish species from a nontidal lagoon of the southern Adriatic Sea (Italy). Transitional Waters Bulletin 3(3):1-9.

Mater, S., Kaya, M., \& Bilecenoglu, M. (2003). Marine Fish Atlas of Turkey. Ege University Fisheries Faculty Press, 68(11): 169 p. (in Turkish)

Mendes, B., Fonseca, P., \& Campos, A. (2004). Weight-length relationships for 46 fish species of the Portugese west coast. Journal of Applied Ichthyology 20:355-361.

Molinero, A., \& Flos, R. (1992). Influence of season on the feeding habits of the common sole Solea solea. Marine Biology 113, 499-507. https://doi.org/10.1007/BF00349177

Morgan, M.J. (2003) Variation with age in the timing and duration of spawning in American plaice. Journal of Fish Biology 62:464-473.

Muus, B.J., \& Nielsen, J.G. (1999). Sea fish. Scandinavian Fishing Year Book, Hedehusene, Denmark. 340 p.

Nash, R.D.M., \& Geffen A.J. (2015). Age and growth, pp. 207-241. In: Flatfishes: Biology and Exploitation, 2nd ed. (Gibson, R. N., R. D. M. Nash, A. J. Geffen, and H. W. Van der Veer, Eds.). New York: John Wiley \& Sons, Ltd.

Oral, M. (1996). Biological aspects of Common Sole (Solea vulgaris Quensel, 1806) in the Sea of Marmara. Phd. Thesis. Istanbul University, Istanbul, $70 \mathrm{p}$.

Özaydın, O., Uçkun, U., Akalın, S., Leblebici, S., \& Tosunoğlu, Z. (2007). Length-weight relationships of fishes captured from Izmir Bay, Central Aegean Sea. Journal of Applied Ichthyology 23(6):695-696.

Parma, L., Bonaldo, A., Massi, P., Yúfera, M., Martínez-Rodríguez, G., \& Gatta, P.P. (2013). Different early weaning protocols in common sole (Solea solea L.) larvae: implications on the performances and molecular ontogeny of digestive enzyme precursors. Aquaculture 414-415:26-35.

Pauly, D. (1980). A selection of simple methods for the assessment of tropical fish stocks. FAO Fisheries Circular No: 729, 54 p.

Pauly, D. (1984). Fish population dynamics in tropical waters: A manual for use with programmable calculators. ICLARM, Manila, Philippines.

Pauly, D. (1993). Fishbyte Section. Editorial. NAGA, The ICLARM Quarterly 16: 26.

Piñeiro, C., \& Saínza, M. (2003). Age estimation, growth and maturity of the European hake (Merluccius merluccius (Linnaeus, 1758)) from Iberian Atlantic waters. ICES Journal of Marine Science 60:10861102.

Quéro, M., Desoutter, M., \& Lagardère, F. 1986. Soleidae. In: Fishes of the North-eastern Atlantic and the Mediterranean, (eds., Whitehead, P.J.P., Bauchot, M.L., Hureau, J.-C., Nielsen, J., Tortonese, E.), Unesco, Paris, pp. 1308-1324.

Ramos, J. (1982). Estudio de la edad y crecimiento del lenguado, Solea solea (Linneo, 1758) (Pisces, Soleidae). Investigaciones Pesqueras 46(1):15-28.

Rijnsdorp, A.D. (1989). Maturation of male and female North Sea plaice (Pleuronectes platessa L.). Journal du Conseil International pour l'Exploration de la Mer. 46:35-51.

Rijnsdorp, A.D., \& Vethaak, A.D. (1997). Changes in reproductive parameters of North Sea plaice and sole between 1960 and 1995. ICES Conferences and Meetings. 1997/U:14.

Sampson, D.B., \& Al-Jufaily, S.M. (1999). Geographic variation in the maturity and growth schedules of English sole along the US west coast. J Fish Biol. 54:1-17.

Shuozeng, D. (1995). Life history cycles of flatfish co-occurring in the Bohai Sea of China. Neth. J. Sea Res. 34:195-210.

Sokal, R.R., \& Rohlf, F.J. (1987). Introduction to Biostatistics, 2nd Edition. Freeman, New York, 363 pp.

Sparre, P., \& Venema, S.C. (1998). Introduction to tropical fish stock assessment. Part 1 - Manual. FAO, Roma. FAO Fisheries Technical Paper 306/1, Rev. 2, 337 pp. 
Sparre, P., Ursin, E., \& Venema, S.C. (1989). Introduction to tropical fish stock assessment, Part 1. Manual. FAO Fisheries Technical Paper. No. 306.1, Rome

Stergiou, K.I., Christou, E.D., Georgopoulous, D., Zenetos, A., \& Souvermezoglou, C. (1997). The Hellenic seas: physics, chemistry, biology and fisheries. p. 415-538. In A.D. Ansell, R.N. Gibson and M. Barnes (eds.). Oceanography and marine biology: an annual review. UCL Press.

Teixeira, C.M., \& Cabral, H.N. (2010). Comparative analysis of the diet, growth and reproduction of the soles, Solea solea and Solea senegalensis, occurring in sympatry along the Portuguese coast. Journal of Marine Biolological Association of the United Kingdom 90(5):995-1003.

TUIK (Turkish Statistical Institute) (2020). https://www.tuik.gov.tr/. 19.12.2020.

Türkmen, M. (2003). Investigation of some population parameters of common sole, (Solea solea (L,. 1758)) from Iskenderun Bay. Turkish Journal of Veterinary and Animal Sciences 27:317-323.

Vasilakopoulos, P., O’Neill, F.G., \& Marshall, C.T. (2011). Misspent youth: does catching immature fish affect fisheries sustainability? ICES Journal of Marine Sciences 68(7):1525-1534.

Veiga, P., Machado, D., Almeida, C., Bentes, L., Monteiro, P., Oliveira, F., Ruano, M., Erzini, K., \& Gonçalves, J.M.S. (2009). Weight-length relationships for 54 species of the Arade estuary, southern Portugal. Journal of Applied Ichthyology 25:493-496.

Vianet, R., Quignard J.P., \& Tomasini, J.A. (1989). Age et croissance de quatre poissons Pleuronectiformes (flet, turbot, barbue, sole) du golfe du Lion. Cybium 13(3):247-258.

Wright, P.J., \& Trippel, E.A. (2009). Fishery-induced demographic changes in the timing of spawning: consequences for reproductive success. Fish and Fisheries 10:283-304.

Wurtz, M., \& Matricardi, G. (1986). An attempt of growth parameter computation for some commercial species of the Tyrrhenian Sea. Rapport Commission international Mer Méditerranean 30(2): 236.

Zhang Y., Chen Y., Zhu J., Tian S. \& Chen X. (2017). Evaluating effectiveness of biological reference points for bigeye tuna (Thunnus obesus) and yellowfin tuna (Thunnus albacares) fisheries in the Indian Ocean. Aquaculture and Fisheries 2(2): 84-93. DOI: 10.1016/j.aaf.2017.01.004 